\title{
Analysis of Factor Affecting Work Stress for Employees in Pamekasan Nursing Academy
}

\author{
Kuzzairi $^{1}$, Byba Melda Suhita ${ }^{2}$ \\ ${ }^{1}$ Magister of Health Study \\ Program of STIKes Surya Mitra \\ Husada Kediri \\ ${ }^{2}$ Lecturer of Stikes Surya Mitra \\ Husada Kediri \\ Email: \\ putramandalatrans@gmail.com
}

Received : October 4, 2018

Accepted : October 6, 2018

Published : November 30, 2018

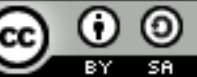

\begin{abstract}
Each workplace always feeds on the potential hazards that may affect the health of the workforce or may cause work-related illness. Psychic disorder is a potential hazard that is often overlooked when the potential of this psychic hazard is also an important factor that needs to be considered in relation to the mental health of workers. Factors that are suspected to be stressors of work stress are the personality, workload, organizational structure and climate, career development and work environment. The purpose of this study is to analyze the factors that affect the work stress of employees Akper Pemkab Pamekasan. The type of this research is quantitative research with analytic observational research design with cross sectional approach. The study was conducted on 12 to 23 February 2018 at Akper Pemkab Pamekasan with a population of 42 employees. The sample size is 38 respondents. The independent variables are personality, workload, organizational structure and climate, career development and work environment. Variable dependent is work stress of Akper employees Pamekasan regency. data were collected using questionnaires. Data were analyzed using logistic regression test with $\alpha=0,05$. The results showed that variable X1 (personality) with $\mathrm{p}=0,639$; $\mathrm{OR}=13,749$, Variable $\mathrm{X} 4$ (career development) with $p=0,028$; OR $=15.270$, variable $X 5$ (working environment) with $\mathrm{p}=0.999$; OR $=1,460$. So it can be concluded that the dominant factor and influence work stress employees Akper Pemkab Pamekasan is career development factor with the influence of 15.270. Employee career development that does not satisfy the cause of work stress so it is necessary to provide information and communication in a transparent and accountable about the mechanism of career development level in accordance with the performance.
\end{abstract}

Keywords: Personality, workload, sturktur and organizational climate, career development, work environment, work stress

Copyright @ 2018 STIKes Surya Mitra Husada All right reserved.

This is an open-acces article distributed under the terms of the Creative Commons Attribution-ShareAlike 4.0 International License.

\section{INTRODUCTION}

Human resource is a central cause in the management of an organization. In achieving the goals of an organization requires human resources as a system manager. Competent human resources with good performance can support business success. Conversely, if the human resource is not 
competent and its poor performance is a competitive issue that can put the company in a losing condition.

Each workplace always feeds on the potential hazards that may affect the health of the workforce or may cause work-related illness. The psychic disorder is a potential hazard that is often overlooked when the potential of this psychic hazard is also an important factor that needs to be considered to the mental health of workers. The occurrence of conflicts within the workforce as a result arising from psychological disorders if not addressed immediately will have an impact on the emergence of stress work. (Tarwaka, 2011)

Stress is all actions of the human body against all stimuli from both outside and inside the body itself that can cause various adverse effects ranging from health decline to the severity of a disease. In relation to work, all the effects of the stress will lead to decreased performance, efficiency and productivity of the work in question (Tarwaka, 2011)

Higher Education is the main pillar of the education system that is as a buffer of quality human resources $\neg$ (Sumarjoko, 2010). Therefore lecturers are an important part that determines whether a university in academics. Lecturers have the roles, responsibilities and tasks to decide the right learning system and form the strong resources that exist in each student for the success of students in the world of work, able to develop science and technology and produce intellectuals, scientists, and / or professionals who are cultured and creative, tolerant, democratic, tough character, and dare to defend the truth for the sake of the nation (Law RI No. 12, 2012).

Based on the preliminary study conducted on November 03, 2017 at the Nursing Academy Pemkab Pamekasan known that the Nursing Academy Pamekasan Regency is a diploma 3 owned by the Regional Government and is the only Nursing Academy in Pamekasan District, established since 1998 and is convert the School Nurse Health (SPK) became the Academy of Nursing. Until now Akper Pemkab Pamekasan has graduated about 2,470 graduates with an average number of students per year about 366 students with 23 lecturers. (Preliminary Study, 2017).

Based on the above background, researchers interested in conducting research with the title "Analysis of Factors Affecting Employment Stress at Nursing Academy Pemkab Pamekasan"..

\section{RESEARCH OBJECTIVES}

1. General Goals

Analyzing factors that affect employee work stress in Pamekasan Nursing Academy.

2. Special Purpose

a. Analyzing the influence of personality on employee work stress in Pamekasan Nursing Academy.

b. Analyzing the influence of workload on employee work stress in Pamekasan Nursing Academy.

c. Analyzing the influence of organizational structure and climate on employee work stress in Pamekasan Nursing Academy.

d. Analyzing the influence of career development on employee work stress in Pamekasan Nursing Academy.

e. Analyzing the influence of work environment on employee work stress in Pamekasan Nursing Academy.

f. Analyzing the most dominant factors affecting employee work stress in Pamekasan Nursing Academy. 
Table 4:47 Personality analysis of work stress employees in Pamekasan Nursing Academy

\begin{tabular}{|c|c|c|c|c|}
\hline & & \multicolumn{2}{|c|}{ Work Stres } & \multirow{2}{*}{ Total } \\
\hline & & Stres & Not stres & \\
\hline \multirow{4}{*}{ Workload } & \multirow{2}{*}{ Overload } & 14 & 1 & 15 \\
\hline & & $36.8 \%$ & $2.6 \%$ & $39.5 \%$ \\
\hline & \multirow{2}{*}{ Underload } & 16 & 7 & 23 \\
\hline & & $42.1 \%$ & $18.4 \%$ & $60.5 \%$ \\
\hline \multirow{2}{*}{\multicolumn{2}{|c|}{ Total }} & 30 & 8 & 38 \\
\hline & & $78.9 \%$ & $21.1 \%$ & $100.0 \%$ \\
\hline
\end{tabular}

Sumber : Data Primer, 2018

\section{METHODS}

The type of this research is quantitative research with analytic observational research design with cross-sectional approach. The study was conducted on 12 to 23 February 2018 at Pamekasan Nursing Academy with a population of 42 employees. The sample size is 38 respondents. The independent variables are personality, workload, organizational structure and climate, career development and work environment. The dependent variable is work stress at Akper Pamekasan employees. data were collected using questionnaires. Data were analyzed using logistic regression test with $\alpha=0,05$.

\section{RESULTS}

1. Analysis of the influence of personality on the occurrence of work stress

Based on the results of research Table 4:47 obtained respondents almost half (44.7\%) who experienced work stress have exstrovet personality. The result of statistical test using logistic regression shows the value of $\mathrm{p}$ value $=0,639>0,05$, then $\mathrm{H} 0$ is accepted, meaning there is no influence of personality factor to work stress employee event in Pamekasan Nursing Academy.

2. Analysis of the effect of Workload on the occurrence of stress work

Based on the results of research Table 4:48 obtained respondents almost half (42.1\%) who experience work stress has the workload underload. The result of statistic test using logistic regression shows the value of $\mathrm{p}$ value $=0,054>0,05$, then $\mathrm{H} 0$ is accepted, meaning that there is no influence of work load factor to work stress employee event in Pamekasan Nursing Academy.

Table 4:48

\begin{tabular}{|c|c|c|c|c|}
\hline & & \multicolumn{2}{|c|}{ Work Stres } & \multirow{2}{*}{ Total } \\
\hline & & Stres & Not stres & \\
\hline \multirow{4}{*}{$\begin{array}{c}\text { career } \\
\text { development }\end{array}$} & \multirow{2}{*}{ not satisfied } & 24 & 3 & 27 \\
\hline & & $63.2 \%$ & $7.9 \%$ & $71.1 \%$ \\
\hline & \multirow{2}{*}{ satisfied } & 6 & 5 & 11 \\
\hline & & $15.8 \%$ & $13.2 \%$ & $28.9 \%$ \\
\hline
\end{tabular}

Sumber : Data Primer, 2018 
3. Analysis of the influence of Organizational Structure and Climate on the occurrence of stress work

Table 4.49 Analysis of organizational structure and climate on work stress employees in Pamekasan Nursing Academy

\begin{tabular}{|c|c|c|c|c|}
\hline & \multicolumn{2}{|c|}{ Work Stres } & \multirow{2}{*}{ Total } \\
\hline & & Stres & Not stres & \\
\hline \multirow{4}{*}{$\begin{array}{l}\text { organizational } \\
\text { structure and } \\
\text { climate }\end{array}$} & \multirow[b]{2}{*}{ UnSupported } & 14 & 1 & 15 \\
\hline & & $36.8 \%$ & $2.6 \%$ & $39.5 \%$ \\
\hline & \multirow{2}{*}{ Supported } & 16 & 7 & 23 \\
\hline & & $42.1 \%$ & $18.4 \%$ & $60.5 \%$ \\
\hline \multirow{2}{*}{\multicolumn{2}{|c|}{ Total }} & 30 & 8 & 38 \\
\hline & & $78.9 \%$ & $21.1 \%$ & $100.0 \%$ \\
\hline
\end{tabular}

Regresi Logistic $p$ Value $=0,100>0,05,0 R=13,749$

Based on the results of research Table 4:49 obtained respondents almost half $(42.1 \%)$ who experienced work stress to feel the structure and climate organization support. The result of statistic test using logistic regression shows the value of $\mathrm{p}$ value $=0,100>0,05$, then $\mathrm{H} 0$ accepted means there is no influence of organizational structure and climate factor to work stress employee in Pamekasan Nursing Academy.

4. Analysis of the influence of Career Development on the occurrence of work stress

Based on the results of the research Table 4.50 obtained respondents most (63.2\%) who experienced work stress to feel his career development is not satisfactory. Statistical test results using logistic regression shows p value $=0,028<0,05$, then $\mathrm{H} 0$ is rejected, it means there is influence of career development factor to work stress employee event in Pamekasan Nursing Academy.

5. Analysis of the influence of work environment to the occurrence of stress work

Based on the results of research Table 4.51 obtained respondents most $(68.4 \%)$ who experienced work stress feel the work environment is good. The result of statistic test using logistic regression shows the value of $\mathrm{p}$ value $=0,999>0,05$, then $\mathrm{H} 0$ is accepted, meaning there is no influence of work environment factor to work stress employee event in Pamekasan Nursing Academy

6. Analisis Multivariat

Table 4.52 Analysis of factors affecting work stress employees in Pamekasan Nursing Academy

\begin{tabular}{cccc}
\hline No & Variabel Independent & $\boldsymbol{P}$ Value & $\boldsymbol{E x p}(\boldsymbol{B})$ \\
\hline 1 & Personality & 0.639 & 1.717 \\
\hline 2 & Workload & 0.054 & 19.163 \\
\hline 3 & Organizational structure and climate & 0.100 & 13.749 \\
\hline 4 & Career development & 0.028 & 15.270 \\
\hline 5 & Work environment & 0.999 & $1.460 \mathrm{E} 8$ \\
\hline \multicolumn{2}{c}{ Alpha value 0.05 } \\
\hline \multicolumn{4}{c}{}
\end{tabular}

Sumber: Data Primer, 2018

Based on the results of research Table 4.52 obtained statistical test results using logistic regression of all independent variables indicate only career development factors that have a value of 
p-value smaller than $0.050 .028<0.05$, the most influential factor for the incidence of work stress employees in Pamekasan Nursing Academy is a career development.

\section{DISCUSSION}

Table 4.51 Work environment analysis of work stress employees in Pamekasan Nursing Academy

\begin{tabular}{|c|c|c|c|c|}
\hline & & \multicolumn{2}{|c|}{ Work Stres } & \multirow{2}{*}{ Total } \\
\hline & & Stres & Not stres & \\
\hline \multirow{4}{*}{$\begin{array}{l}\text { Work } \\
\text { environment }\end{array}$} & \multirow{2}{*}{ No good } & 4 & 0 & 4 \\
\hline & & $10.5 \%$ & $.0 \%$ & $10.5 \%$ \\
\hline & \multirow{2}{*}{ good } & 26 & 8 & 34 \\
\hline & & $68.4 \%$ & $21.1 \%$ & $89.5 \%$ \\
\hline \multirow{2}{*}{\multicolumn{2}{|c|}{ Total }} & 30 & 30 & 8 \\
\hline & & $78.9 \%$ & $78.9 \%$ & $21.1 \%$ \\
\hline
\end{tabular}

A. The influence of personality on work stress employees in Pamekasan Nursing Academy.

Based on the results of this study showed that of 38 respondents only almost half $(44.7 \%)$ who have extrovert personality experienced work stress. The result of the statistical test using logistic regression got the value $p=0,639$ with OR 1,717 . Because the value of $p>0.05$ then $H 1$ rejected which means there is no influence of personality to the occurrence of stress work at employees in Pamekasan Nursing Academy. From the statistical test results obtained OR value 1717, this means that the opportunity factor personality does not affect work stress in employees in Pamekasan Nursing Academy of 1.717 .

The results of this study are not in line with the results of research Jannah (2015) which states there is a significant relationship between the personality with work stress on nurses intensive space general hospital dr. Zainoel Abidin Banda Aceh with p-value 0.00. The results of this study are also not aligned with Andi's research (2013) which states there is a significant influence on the type of personality with work stress employee religious training center Manado. According to Robbin (2001) in a person is divided into 2 personality that is personality type A and personality type $\mathrm{B}$, but that personality that influences on job stress is type A. Personality type A is personality which involves aggressively in the continuous struggle to reach less time and resisting opposing attempts from other people or things. Of this type is a personality that is easy to stress because this type is more aggressive, easy to panic, always cautious and likes to challenge.

According to Nasution (2000), when talking about work stress on workers then we will see how someone views stress as a disorder so that stress depends on the personality of the affected person. People with personality type A are more susceptible to stress than personality type B, with introvert personality type is more stressful than the extrovert personality type.

The life experiences of people who have experienced past failures will easily make them judge failure as a matter of course. People who are immature in the face of a case will easily waver in the attitude, stance, and direction of his life than people who have mature personality.

The results of this study are not in accordance with the theory of Robbin (2001) and Nasution (2000) who said that the type of personality type A (introvert) more easily stress than type B type (extrovert). This is because of the characteristics of respondents, among others, age, years of service, education. Age of respondents almost entirely entered adulthood so that in the face of stressors have experienced and can finish with wise and wise. From the work period is also the cause of no relationship between the personality with work stress, this is evidenced by almost all employees in Pamekasan Nursing Academy has a working period of more than 5 years, so that employees have been able to adapt to the conditions of the situation and organization climate in Akper Pemkab Pamekasan. In addition, the latest education employees in Pamekasan Nursing Academy are almost entirely educated undergraduate and masters so that their education is able to understand how to do stress management 


\section{B. Effect of workload on work stress employees in Pamekasan Nursing Academy.}

Based on the results of this study showed that from 38 respondents almost half (42.1\%) have workload underload but experienced work stress. The result of a statistical test using logistic regression was obtained $p$-value $=0,054$ with OR 19.163. Because the value $p>0.05$, then H1 rejected which means there is no effect of workload on the stress of work at employees in Pamekasan Nursing Academy. From the statistical test results obtained OR 19.163, this means that the opportunity factor workload does not affect the occurrence of work stress at employees in Pamekasan Nursing Academy of 19.163 .

The result of this research is in line with the result of research of Azizah (2013) which states there is no relationship between workload with work stress where the p-value is 0300 . The results of this study are also in line with research Herawati (2006) which states there is no significant relationship between workload with job stress where p-value 0.356 .

The results of this study are not in harmony with the results of research Novayanti (2012) which states there is a relationship between workload with job stress where the value p-value 0.0001 and Rahmaniaty (2010) research results also state there is a significant relationship between workload with job stress with p-value 0.011 .

The workload according to Meshkati in Hariyati (2011) can be defined as a difference between the capacity or the ability of the worker to the demands of the work to be faced. Considering that human labor is both mental and physical, each has different levels of loading. Excessively high loading rates allow excessive energy consumption and overstressing, otherwise, the overloading intensity enables boredom and saturation or under stress. Therefore it is necessary to strive for the best level of loading intensity that exists between the two extreme limits and of course different between people with each other.

There is no effect of a workload with work stress on employees in Pamekasan Nursing Academy because employees' workload in Pamekasan Nursing Academy is in accordance with a standard, role, and the ability of each employee so that work was done by employees is a job that is in accordance with the ability. In addition, the number of employees in Pamekasan Nursing Academy totaling 42 people has a ratio of 1 to 8 with 355 students. In addition, based on the analysis of items about workload, it is found that the work time of employees on campus is enough to complete all the work without the need to be brought home and if getting an increased workload, employees are given enough rest time to recover energy.

C. The influence of structure and work climate on work stress employees in Pamekasan Nursing Academy.

Based on the results of this study showed that from 38 respondents almost half (42.1\%) who feel the structure and climate of the organization support but experienced work stress. The result of the statistical test using logistic regression was obtained $p=0,100$ with OR 13,749 . Because $p>0,05$, $\mathrm{H} 1$ is rejected which means that there is no influence of organizational structure and climate to the occurrence of work stress at employees in Pamekasan Nursing Academy. From the statistical test results obtained OR 13,749, this means that the opportunity factor structure and organizational climate does not affect the occurrence of stress at employees in Pamekasan Nursing Academy of 13.749.

The results of this study are in line with the research of Azizah (2013) which states there is no relationship between organizational structure and climate with work stress where p-value 0.068 . Setyani research (2013) also states there is no relationship between organizational structure and climate with work stress with p-value 0.106. So also research sharma (2013), Hendra (2013) and abdillah (2016) stating that the climate organization does not affect the stress of work.

The results of this study are not in line with the theory Wantoro, 1999 which organization climate is one factor that can cause stress work, policies and management companies that are too tight, sanctions are burdensome, is the cause of employee tension.

Poor organizational structure and organizational climate and lack of support of employees can usually lead to dissatisfaction in work that can eventually cause stress (Munandar 2001). 
Anggraeiny, Yehezkiel \& Masjaya (2013) describes when the organization's climate is perceived by members of the organization is good, then members of the organization will respond positively so that will improve performance. A good organizational climate will have a positive impact on the employees themselves, such as job satisfaction and commitment to the organization. But if employees feel the organization's climate is not good then employees will feel uncomfortable at work, anxious and depressed during work so that employees will experience stress work.

Structure and organizational climate in Pamekasan Nursing Academy good so it does not become a factor that affects the work stress on employees in Pamekasan Nursing Academy. It is proven that most (60\%) of employees feel the structure and climate of the organization in employees in Pamekasan Nursing Academy support to employee's job like policy and regulation about employee work flexible, all employees are involved in every meeting and its opinion is heard by leader especially related to its job.

D. The influence of career development on work stress of employees in Pamekasan Nursing Academy.

Based on the results of this study showed that of 38 respondents most (63.2\%) whose career development is not satisfactory experiencing work stress. The result of statistic test using logistic regression is obtained p-value $=0,028$ with OR 15.270. Because p-value $<0,05, \mathrm{H} 1$ is accepted which means there is an influence of career development on job stress incident on Akper employees of Pamekasan Regency. From the statistical test results obtained OR 15,270, this means that respondents who career development are not satisfactory, the opportunity to experience work stress of 15.270 times greater than the development of a satisfactory career.

Career development is defined as an entity consisting of elements of one's activities in life to develop and improve themselves, the elements of organizational activities in developing employees where the activity is executed formally by the organization with the aim of getting the balance between each career with a determined career path organization (Bernadin 2013).

Career development is very important for both people and organizations. Career development practices as reported in 2013, proven to increase employee career satisfaction and improve organizational effectiveness. Employees such as those who do not see many opportunities to get ahead or even none at all will experience frustration which can lead to a decrease in organizational commitment decreased performance and increased the desire for exit from the organization.

The results of this study are not in line with Amalia e tal research (2017) which states there is no relationship between career development and job stress in teachers SLB Negeri Semarang with pvalue 0,092 . Setyani's research (2013) also states there is no relationship between career development and job stress with p-value 0, 345, as well as Desy's research (2002), Airmayanti (2009) stated no relationship between career development and job stress with a p-value of each - respectively by 0.10 and 0.193 .

Career development is a potential stress generator that includes job uncertainty, overpromotion, lack of promotion, insecurity in work, fear of being excluded from work because there is no more work to be done, retiring too early, frustrating with what one's career has achieved (Munandar, 2001).

Career development becomes a factor that affects the stress of employee work Pamekasan Nursing Academy. This is because related to the status of institutional Akper who must merge with the college and if not then it must be washing out or closed so that employees feel the future is not clear and the fear of washing out so really happened and required to find other jobs that would need time and adaptation again. Based on the analysis of items obtained employees feel dissatisfied with the promotion or promotion and often feel bored in doing activities that are always the same every day. This is not apart from the institutional status of Akper Pemkab Pamekasan which is owned by the local government where the policies and regulations on employees are not the same with the policies and regulations on lecturers and employees at a college.

E. Effect of work environment on work stress of Akper employees of Pamekasan Regency. 
Based on the results of this study showed that of 38 respondents most (68.4\%) good working environment but experienced work stress. The result of the statistical test using logistic regression was obtained $p$-value $=0.999$ with OR $1,460 \mathrm{E} 8$. Because the value $\mathrm{p}>0.05$, then $\mathrm{H} 1$ rejected which means there is no effect of the work environment on the incidence of work stress on employees Akper Pemkab Pamekasan. From the statistical test results obtained OR 1.460E8 tilapia, this means that the chances of work environment factors do not affect the occurrence of work stress on employees Akper Pemkab Pamekasan of 1.460E8.

The result of this research is in line with Setyani (2014) research which stated that there is no influence of both physical and nonphysical work environment on work stress with p-value 0.071 and 0.138. the results of research Rahmniaty (2010) also showed no effect of work environment with work stress where p-value 0.560 .

However, the results of this study contradict with research Rizki et al (2016) who examines the influence of work environment on job stress on employees of PT PLN Malang which states there is an influential work environment with job stress with p-value 0.007. Research Pasih (2013) entitled the influence of work environment to the work stress of nurses at RS Muhammadiyah Jombang also stated there is influence of working environment both physical and nonphysical work environment with job stress with p-value 0,011 and 0,033 .

The work environment is very important to support work activities so that with adequate equipment, facilities and atmosphere, employee relations with one department, employee relationships with superiors can create good communication and a solid system of coöperation when completing tasks and responsibilities to decrease work stress.

Poor working relationships are revealed in symptoms of low trust, low level of support and low interest in problem-solving within the organization. Distrust is positively associated with high role ambiguity, which leads to inappropriate personal communication between workers and psychological tensions in the form of low job satisfaction, a deterioration of health and feels threatened by superiors and co-workers (Munandar 2001 ).

According Sedarmayanti (2009) work environment is the overall tooling tools, materials faced, environment, working methods around the workers and arrangements work both as people and groups. In general, the working environment is divided into two parts namely the physical and nonphysical work environment. The physical work environment is all things that are located around where a person works, which directly or indirectly can affect in carrying out his work. While the nonphysical work environment is all that happens in associated with the relationship work, both relationships with superiors or relationships with colleagues, and relationships with subordinates.

Work environment both physical and social in Pamekasan Nursing Academy good so it does not become a factor that affects employees stress in Pamekasan Nursing Academy. It is proven that the lighting conditions are very good and there is no noise so it is very supportive of employees and can focus on doing the job. In addition, Akper Pemkab Pamekasan has complete facilities and the room all air-conditioned. The working period of employees in Pamekasan Nursing Academy almost entirely has a working period of more than 5 years so that each employee already knows the character of everyone so that the relationship between employees well established.

F. The most dominant factor affecting employee work stress in Pamekasan Nursing Academy.

Based on statistical test of logistic regression obtained $\mathrm{P}$ value on career development factor $=$ 0,028 ; $\mathrm{OR}=15.270$. This means that if the employee has an unsatisfactory career development, then the employee is at risk of experiencing work stress 15,270 times greater than employees who have a satisfactory career development. So it can be concluded that the most dominant factor affect $Y$ (work stress) is a career development factor with the effect of 15.270 times.

The results of this study in line with the results of research Karima (2014) which shows the most dominant factor affecting job stress on workers XX is the uncertainty of work. In addition, the results of this study are also in line with the results of research conducted on workers where the results show that job uncertainty is much related to increasing absenteeism (Chirumbolo \& Areni, 2005). The results of research on hospital workers also indicate a significant relationship between job uncertainty and job stress (Zyl, Eeden \& Rothmann, 2013). 
The result of this research is different from earlier research done by Iwan and Uli (2015) which examines the factors that influence work stress of employees of PT Perkebunan Nusantara IV Kebun Tobasari Sumatera Utara, where the result shows that the most dominant factor affecting employee's work stress is role conflict with p-value 0.758. This research also differs from Suryawan's research result (2017) which the result shows that the most dominant factor influencing job stress on city cleaners in Gianyar Regency Environment Office is interpersonal demands with an eigenvalue of 6,492 .

The uncertainty of work perceived by workers can lead to low worker commitment to the organization and increase worker turnover. For workers, their future job uncertainty can be perceived as a threat because it has serious consequences that can drastically change a person's life and change lifestyle unexpectedly (Perrewe \& Ganster 2011).

Job uncertainty may also occur due to possible job changes and possible future skills. Concerns about job uncertainty can occur when a company's merger situation works. These concerns may increase the risk of stress on the person. Such prolonged stress can have an impact on the emergence of psychological and physical disorders. In addition, these concerns can also trigger fatigue in work. (Robbins, 2009).

\section{CONCLUSION}

1. The results obtained $\mathrm{p}$-value $=0.639 ; \mathrm{OR}=1,717$ which means there is no influence of personality to work stress employees in Pamekasan Nursing Academy

2. The results obtained $\mathrm{p}$-value $=0,054 ; \mathrm{OR}=19,163$ which means there is no influence of workload on work stress employees in Pamekasan Nursing Academy

3. The result of analysis got $\mathrm{p}$-value $=0,100 ; \mathrm{OR}=13.749$ which means there is no influence of organizational structure and climate on work stress employees in Pamekasan Nursing Academy

4. The results obtained $\mathrm{p}$-value $=0,028$; $\mathrm{OR}=15,270$ which means there is an influence of career development on work stress employees in Pamekasan Nursing Academy

5. The results obtained $\mathrm{p}$-value $=0.999 ; \mathrm{OR}=1,460 \mathrm{E} 8$ which means there is no effect of the work environment to work stress employees in Pamekasan Nursing Academy.

The most dominant factor affecting employee stress in Pamekasan Nursing Academy is career development with $\mathrm{p}$-value $=0,028 ; \mathrm{OR}=15.270$.

\section{REFERENCE}

Mohammad Rasyid, A. Dkk. (2016). Dampak Iklim Organisasi Terhadap Stres Kerja Dan Kinerja Karyawan. Fakultas Ekonomi Universitas Riau.

Ahmad Subekhi, M. M., \& Jauhar, M. S.Pd. (2012). Pengantar Manajemen Sumber Daya Manusia (Msdm). Prestasi Pustaka. Jakarta.

Amalia. Dkk. (2016). Pengaruh Stres Kerja Terhadap Kinerja Karyawan. Univeritas Pendidikan Ganesha Singaraja. Indonesia.

Rahman Giu, A. (2013). Pengaruh Desain Organisasi Dan Tipe Kepribadian Terhadap Stres Kerja Pegawai Pada Balai Diklat Keagamaan Manado.

Anggraeiny, R., Yehezkiel \& Masjaya. (2013). Pengaruh Kepemimpinan Dan Iklim Organisasi Terhadap Kinerja Karyawan Pada Uptp Pengembangan Produktifitas Daerah Disnakertrans Propinsi Kalimantan Timur. E-Journal Administratif Peform.

Anonim. Risiko Buruk Bagi Pekerja Stres. (2012). (Http://Www.Mediaindonesia.Com/Me Diahidupsehat/Index.Php/Read/2012/0 9/17/5626/5/Risiko-Buruk-Bagipekerja-Stres Diakses Tanggal 1 September 2012).

Anonim. Stress: Constant Stress Puts Your Health At Risk. (2010) (Http://Www.Mayoclinic.Com/Health/Str Ess/Sr00001 Diakses Tanggal 1 Agustus 2012). 
Hendra, A. (2013). Pengaruh Iklim Organisasi Terhadap Komitmen Organisasional Dengan Kepuasan Kerja Sebagai Variable Intervening Pada Karyawan Pt Garam (Persero).

Suharsimi, A. (2006). Prosedur Penelitian Suatu Pendekatan Praktek. Edisi Revisi. Pt. Rineka Cipta Jakarta.

Diah, A. (2009). Factor-Faktor Yang Mempengaruhi Stres Kerja Pada Pekerja Bagian Produksi PT Ism Bogasari Flour Mills Tbk. Jakarta. Skripsi Uin Syarif Hidayatullah.

Khamim, B. (2013). Hubungan Tipe Kepribadian Terhadap Stres Kerja Perawat Ruang Icu RSUD Margono Soekarjo, Purwokerto.

H. John, B., \& E. A. Russel, J. (2013). Human Resource Management An Experiential Approach. Megrow Hill. Singapore.

Budiarto, E. (2016). Metode Penelitian Kedokteran Sebuah Pengantar. Jakarta EGC.

Chirumbolo \& Arena (2015). The Influence Of Job Insecurity On Job Performance And Absteeisme. Sa Journal Of Industrial Psychology.

Vita Helia D. (2002). Tingkat Stres Dan Faktor-Faktor Yang Berhubungan Dengan Stres Kerja Pada Karyawan Bagian Marketing Service Pt Unilever Indonesia. Skripsi Fakultas Kesehatan Masyarakat Ui Depok.

Syaiful Bahri, D. (2000). Guru Dan Anak Didik, Dalam Interaksi Edukatif. Jakarta. Rineka Cipta.

Azizah Musliha F. (2013). Analisis Faktor-Faktor Yang Berhubungan Dengan Kejadian Stres Kerja Pada Karyawan Bank Bmt. Tesis. Universitas Diponegoro.

T. Hani, H. (2001). Manajemen Personalia \& Sumber Daya Manusia Cetakan Ke-15, Yogyakarta: BpfeYogyakarta.

Handoko, T. H. (2011). Manajemen Personalia Dan Sumberdaya Manusia. Edisi Kedua. Cetakan Kedelapan Belas. Penerbit Bpfe. Yogyakarta

Handoyo, S. (2011). Stres Pada Masyarakat Surabaya. Jurnal Insan Media Psikologi. Surabaya: Fakultas Psikologi Universitas Airlangga.

Hariyati, M. (2011). Pengaruh Beban Kerja Terhadap Kelelahan Kerja Pada Pekerja Linting Manual Di PT Djitoe Indonesia Tobacco Surakarta. Universitas Sebelas Maret Surakarta.

Perrewe, \& Ganster. (2011). Exploring The Work And Non-Work Interface. Usa Elsevier.

Rahmaniaty, (2010). Analisis Faktor-Faktor Yang Berhubungan Dengan Stres Kerja Karyawan Di Bidang Rekam Medik Rumah Sakit Kanker "Dharmais". Depok Fkm Ui.

Sedarmayanti. (2009). Sumber Daya Manusia Dan Produktifitas Kerja Bandung. CV Mandar Maju.

Sharma, P. (2013). Study Of Organizational Climate And Stres Of Police Personel. International Journal Of Advanced Research In Management And Social Sciences.

Suhita, Melda. (2017). Metodologi Penelitian Kesehatan. Ponorog Forum Ilmiah Kesehatan.

Sumarjoko, B. Kontribusi Kepemimpinan Dan Budaya Organisasi Melalui Kompetensi Terhadap Peran Dosen Dalam Penjaminan Mutu Pts Sekaresidenan Surakarta. Jurnal Varia Pendidikan, Vol. 22, No. 2010.

Tarwaka. Ergonomi Industri, Dasar-Dasar Pengetahuan Ergonomi Dan Aplikasi Di Tempat Kerja. Surakarta: Harapan Press. 2011.

Zyl, Eeden \& Rithmann 2013. Job Insecurity And The Emotional And Behavioral Consequences. Journal Bussiness Management. 44. 
Analysis of Factor Affecting Work Stress for Employees..... 